\title{
Timeliness and Relevance of Financial Reporting in Nigerian Quoted Firms
}

\author{
John Ohaka ${ }^{1, *} \&$ Fyneface N. Akani \\ ${ }^{1}$ Rivers State University of Science \& Technology, Port Harcourt, Nigeria \\ ${ }^{2}$ University of Port Harcourt, Choba, Rivers State, Nigeria \\ *Correspondence: Rivers State University of Science \& Technology, Port Harcourt, Nigeria. E-mail: \\ johnohaka@gmail.com
}

Received: Apr 14, $2017 \quad$ Accepted: April 21, $2017 \quad$ Online Published: April 27, 2017

doi:10.5430/mos.v4n2p55 URL: https://doi.org/10.5430/mos.v4n2p55

\begin{abstract}
Financial accounting standards emphasize timeliness as one of the key components of decision-driven informational relevance. Accordingly, if information is not available as and when due but rather made available so late that it bears no value for future action, then it is operationally irrelevant. To fulfil their primary objective and be useful, therefore, financial reports are expected to be characterized by relevance, reliability, completeness, and timeliness. Against this background, this study examined the relationship of firm size and board independence respectively to the timeliness of financial reporting in companies quoted on the Nigerian Stock Exchange (NSE). Secondary data pertaining to the firms were derived from their annual reports and the NSE Fact Book for 12 years (2000-2011). Analysis of the research data involved test of multicollinearity, heteroskedasticity, and autocorrelation; while the multiple regression technique facilitated the test of research hypotheses. The results established a significant relationship between firm size and timeliness of financial reporting; while in the case of board independence, the relationship was not significant. Consequently, it is recommended that regulatory bodies should ensure better of enforcement of standards relating to timeliness so that financial reports of the firms will be of higher value to key stakeholders.
\end{abstract}

Keywords: financial reports; quoted firms; shareholders' interest

\section{Introduction}

Financial statements are aimed at providing quality financial information for the evaluation of the performance of firms. They facilitate informed decision making as the content is of great value to users of statements. The information in corporate annual reports may be used to influence shareholders' impression of a firms' performance (Ilaboya, 2005). Thus, financial information is very vital to investors and other users of financial statements since it serves as a basis for financial decisions.

Timeliness is one of the qualitative attributes of useful information. The shorter the time between the end of the accounting year and publication date, the more beneficial the audited annual reports will be (Abdulla, 1996). One major reason for late publication of annual reports by quoted firms is that the accounts have to be audited before publishing. The relevance of accounting information disclosed in annual reports decline as the time lag increases. One major determinant of stock price movement on the stock exchange is the timely rendering of financial information by quoted companies as statutorily required. This early rendering of financial reports enables investors to evaluate the risk and expected returns of the firms. The return on a stock relates to the anticipated dividend and any expected capital gains derived from the stock price movements in the market. This evaluation enables investors to determine stocks to purchase and those to sell which is done if the corporate financial report is published on time. Thus, if firms do not provide timely reports, the relevance of the information is compromised.

Against this backdrop, studies on the timeliness of accounting information have become very important, especially in view of the phenomenal changes in modern technology and business practice worldwide. Timely reporting in emerging capital markets is of particular importance since information in these markets is relatively limited and has a longer time lag. It will enhance decision making and reduce information asymmetry in the markets. Furthermore, examination of 
the determinants of timely reporting is crucial to regulators of the capital market who are involved in formulating policies that will enhance market efficiency. This study addresses these issues as they relate to firms quoted on the Nigerian Stock Exchange (NSE). The research questions are:

i. To what extent is firm size related to the timeliness of financial reporting in Nigerian quoted firms?

ii. To what extent is board independence related to the timeliness of financial reporting in Nigerian quoted firms?

The hypotheses are:

Ho1: There is no significant relationship between firm size and timeliness of financial reporting in Nigerian quoted firms.

Ho2: There is no significant relationship between board independence and timeliness of financial reporting in Nigerian quoted firms.

\section{Literature Review}

This study is based on concepts from the Stakeholders Theory and the Agency Theory. The Stakeholders Theory, in organizational management and business ethics, emphasizes significance of moral values in corporate affairs. By the theory, a stakeholder is defined as any group or individual who is affected by the achievement of a firm. Thus, the stakeholders and the firm are interdependent. The stakeholders have legitimate claims on a firm, which are established through exchange-driven relationships (Basu, 1997; Givoly \& Palmon, 1982; Iyoha, 2012). The growing information needs of stakeholders have operational bearing on financial reports, resulting in the quest for timely and credible financial reports. The relationship of stakeholder trust and timely company information is also critical. Relationships depend on trust in one form or another, and this is defined as belief without full information (Tomkins, 2001). In the relationship between managers and stakeholders, there is the tendency of information asymmetry. Business leaders may influence the information provided to stakeholders, which often complicate the pertinent issues. Business leaders who are perceived as being open and willingly to provide information could contribute to boost trust not only in the relationship framework but also for the managers themselves as they inter-relate.

Management may also increase the degree of trust in the relationship between the company and its stakeholders by selecting communication channels and experts who would provide the needed information to stakeholders in a timely manner to avoid loss of relevance. This is also where the issue of asymmetric timeliness has to be addressed. The asymmetry arises when, for example, good or bad news is reported more or less rapid. This good/bad news example is a factor of influence on reporting lag that is featured in many researches on reporting lag (Chambers \& Penman, 1984). One critical situation in this regard is conservatism, where bad news should be reported in an earlier stage than good news. However, the reporting of bad news quicker than good news is not always supported. It is also believed that managers usually attract incentives for time earning announcements. Accordingly, the Stakeholder Theory contends that, in the absence of an opportunity to hide bad news due to mandatory disclosure requirements, managers have incentive arising from the delay in the release of information and subsequent imputation gradually into share prices (Watts \& Zimmerman, 1990; Aondona, 2016).

On the other hand, the Agency Theory suggests that a greater proportion of outside directors could monitor any self-interest by managers and so minimize agency costs. According to Kelton \& Yang (2008), a high percentage of independent directors on board could intensify the monitoring of managerial opportunism. In so doing they succeed in reducing management's chance of withholding information (in a timely manner). Consequently, a board dominated by independent non-executive directors who are free from management interests tend to enhance firm's compliance with disclosure requirements, which may lead to timely financial reporting.

Essentially, as timeliness is regarded as an important qualitative characteristic of accounting, it stands out as a fundamental element of the relevance of financial reporting information. It is one main measure of transparency and quality of financial reporting, measured by the lapse of time between a firm's year-end and the date of release of financial information to the public. For instance, issuing excellent, accurate and comprehensive financial information for two or three year-end is not as desirable as issuing less comprehensive and complete financial statement in a few months after year-end. Financial information may become stale after a few months, and more so, after two or three years. The staler the financial report, the less relevant it is to users, especially potential investors and creditors. Conceptual frameworks, thus, require that accounting information be timely in order to retain its relevance to financial decision makers. 
However, in spite of the importance of timeliness, there have not been much systematic theoretical/empirical analyses of its related variables with respect to quoted firms in Nigeria. From information economics perspective, an information system is conceived as having a shorter reporting delay than another which is more informative, provided both systems ultimately report the same information. The latter assumption is crucial since it assumes that the reliability of information is constant irrespective of timeliness. This may not hold in practice due to timeliness/accuracy trade-offs. As much as it remains important, timeliness does not override financial reporting perspectives due to the potential trade-offs between the timeliness and quality of information (Suphap, 2004). Preparers of accounts tend to sacrifice the reliability of information by focusing largely on timeliness, because lack of timeliness may cause information to have zero utility for decision making and/or information available from other sources (Bromwich, 1992). The late information then results in poor allocation of capital, even as outside investors and creditors are subjected to adverse choice and moral hazards (Leventis \& Weetman, 2004). Where there is less separation of power and control, timeliness of information is still crucial to creditors and external shareholders. Therefore, whether analysts regard timeliness as an objective of accounting or an attribute of useful accounting information, it is obvious that in disclosure regulations and much of accounting literature, timeliness is necessary for financial statements to remain relevant (Nwanyanwu, 2006; Amah, 2015).

For analytical purposes, many researchers in this regard are interested in examining:

i. Audit delay, which represents the number days elapsed between the balance sheet date and the date auditor endorses the financial statements;

ii. Financial statement issue delay, which represents the number of days elapsed between the balance sheet date and the date on which notice for the Annual General Meeting (AGM) along with a copy of the annual report is issued; and

iii. AGM delay (total delay), which represents total delay, that is the number of days elapsed between the fiscal year-end date and the day on which the AGM is actually held.

Although regulatory requirements exert significant influence on financial reporting timeliness, it remains a considerable discretion when firms release financial statement information within regulatory windows. The stock exchange and allied bodies equally require listed companies to publish their audited accounts within a specified period after the end of their accounting year. In Nigeria, companies quoted on the stock exchange are required to present their corporate annual report within six months from their accounting year end. The preparation of financial statements is a statutory duty vested in the directors of the firm.

As conceptualized in this study, the timeliness of release of an annual report is function of the reporting company's size and independence of board members. Atiase, Bamber \& Tse (1989) revealed that large firms usually report earnings relatively early, but the associated market reaction tends to be small due to the firm size effect. The large companies have come to be reckoned with as timely reporters for several reasons, such as:

i. $\quad$ Availability of more accounting staff;

ii. Ability to install and operate modern operating devices that facilitate processing and monitoring inventories and production;

iii. Availability of strong internal control systems which makes the auditors to spend less time in conducting compliance and substantive tests; and

iv. Availability of relatively large number of financial analysts who usually rely on timely release of annual reports to confirm and revise their expectations of companies present and future economic prospects.

Operationally, the large firms appear to be more visible, even as they face so much pressure from the media and allied publics to release financial information quicker (Owusu-Ansah, 2000; Ahmed, 2003). Financial analysts may thus interpret undue delay in reporting as an attempt to conceal information and this may adversely affect the value of the firm. On the other side, there is an incentive for such firms to provide timely reports in order to avoid speculative trading on their shares. The large firms are also believed to have more resources to institute and enforce strong internal control systems for continuous audit functions in the firms. All these considerations tend to ease the audit of large number of transactions in a relatively shorter time, and this is further supported by availability of more resources to pay relatively higher audit fees and ability to settle the fees soon after the companies' year-end. With the foregoing, it is understandable why the audit reporting lag for larger companies is less than that of the smaller firms. Analysts also view management of larger firms as having greater incentive to reduce both audit delay and reporting delay, particularly as they are closely monitored by investors, trade unions and regulatory agencies. 
With respect to board independence, the focus of stakeholders had been mainly on monitoring of corporate financial accounting, especially as it affects reliability and timeliness of financial reports. In this regard, positive correlation is perceived to exist between the proportion of outside directors and disclosure levels. Categorically, a study conducted by Beasley (1996) revealed that the proportion of independent directors on board was positively related to the board's ability to influence disclosure decisions. Kelton \& Yang (2008) also established in their investigation that having a high percentage of independent directors on the board enhances the monitoring of managerial opportunism and decreases management's chance of withholding information. Furthermore, the investigations carried out by Haniffa \& Cooke (2002) emphasized the association between board independence and timeliness of financial reporting in the affirmative. This study, thus, examines these issues, clearly focusing the relationship between timeliness of financial reporting and firm size as well as board independence, particularly as they relate to what obtains in firms quoted on the NSE.

\section{Methodology}

The design of this study is directed at analysing the timeliness of corporate financial reporting in relation to firm size and board independence in companies quoted on the NSE. It involves the use of time series of 12 years frame, spanning 2000- 2011. The study population consists of the 198 firms quoted on the NSE as at 2011, of which a standard sample size of 50 was adopted for analysis. Accordingly, the secondary data were obtained from the financial statements of the various firms and from the NSE Fact Book for the specified years. The data analysis techniques included pooled regression approach, adopted in testing whether two or more independent variables affect a dependent variable. Where a given dependent variable is influenced by several independent variables, the multiple regressions analysis is considered more appropriate (Spiejel \& Stephens, 2011). Consequently, many analysts applaud the features of the multiple regression approach in terms of the triple analytical rationale which manifest it as:

i. Tool for providing an estimate of a dependent variable in relation to many independent variables;

ii. Tool for obtaining a measure of statistical error in the process of empirical estimation; and

iii. Tool for estimating the degree of variance in the dependent variable caused or explained by the independent variables.

Also, descriptive statistics and Pearson Product Moment Correlation matrix were employed to show the degree of relationship between the variables specified in the study. The comprehensive model, which was adapted from Lyoha (2012), features firm size (FS) and board independence (BI) alongside firm performance (FP), debt (DB), age (AG), and uncertainty error term. The model specification, which has time delay (TD) as subject of the function, is expressed as follows:

$\mathrm{TD}=f(\mathrm{BI}, \mathrm{FS}, \mathrm{F}, \mathrm{DB}, \mathrm{AG})$

$$
\text { ... Equation } 1
$$

When expanded, the model is expressed in a fuller econometric form, as:

$\mathrm{TD}=\beta_{0}+\beta_{1} \mathrm{BI}+\beta_{2} \mathrm{FS}+\beta_{3} \mathrm{FP}+\beta_{4} \mathrm{DB}+\beta_{5} \mathrm{AG}+\mathrm{U}_{\mathrm{t}}^{\prime} \quad \ldots$ Equation 2

In this context:

i. TD represents the number of days between the financial year-end date and the day in which the annual general meeting date;

ii. BI is used as proxy for corporate governance, measured by the ratio of non-executive directors to the board size;

iii. FS is measured using the logarithm of total assets of the firm;

iv. FP is measured using the earning per share (EPS); and

v. DB is measured using the leverage of the firm which is measured using the ratio of total debt to total assets.

Thus, the a'priori expectation is:

$$
\beta_{0}>0, \beta_{1}<0, \beta_{3}<0, \beta_{4}<0, \beta_{5}<0, \beta_{6}<0 \beta_{7}<0
$$

Furthermore, diagnostic tests, including variance inflation factor (VIF), are conducted to ensure reliability and validity of the research results.

\section{Data Analysis \& Results}

Majorly, the analysis of data generated for this study involved test of multicollinearity, heteroskedasticisity and 
autocorrelation. The relevant tools relating the above test dimensions were VIF, white heteroskedasticity test, and Breush - Pagan - Godfrey LM test. The details of statistical analysis are presented in Tables 1, 2, and 3; with the facilitating statistical package capturing the comprehensive variables as FIRMSIZE, DEBT, PERF, AGE, and BDIND:

Table 1. Variance Inflation Factor (VIF) Analysis

\begin{tabular}{llll}
\hline Variable & Coefficient Variance & Uncentered VIF & Centered VIF \\
\hline C & 6109.241 & 39.88609 & NA \\
FIRMSIZE & 134.9837 & 40.66736 & 1.036295 \\
DEBT & 0.832882 & 1.006007 & 1.003391 \\
PERF & 831.9760 & 1.025317 & 1.021278 \\
AGE & 0.001065 & 1.079320 & 1.019258 \\
BDIND & 144.6797 & 1.219709 & 1.012980 \\
\hline
\end{tabular}

Source: Research Data (Computed from various years)

Table 2. Heteroskedasticity Analysis

\begin{tabular}{llll}
\hline F-statistic & 1.441860 & Prob. F(5,888) & 0.2067 \\
Obs*R-squared & 7.199561 & Prob. Chi-Square(5) & 0.2062 \\
Scaled explained SS & 250.2990 & Prob. Chi-Square(5) & 0.0000 \\
\hline
\end{tabular}

Source: Research Data (Computed from various years)

Table 3. Autocorrelation Analysis

\begin{tabular}{llll}
\hline Breusch-Godfrey Serial Correlation LM Test: & & \\
\hline F-statistic & 2.582520 & Prob. F(2,885) & 0.0762 \\
Obs*R-squared & 5.187291 & Prob.Chi-Square(2) & 0.0747 \\
\hline
\end{tabular}

Source: Research Data (Computed from various years)

The results of test of hypotheses are presented in Tables 4 and 5:

Table 4. Hypothesis 1 Test Results

\begin{tabular}{lrccr}
\hline Variable & Coefficient & Std. error & t-statistic & Prob. \\
\hline C & 671.7392 & 79.70469 & 8.427850 & 0.000000 \\
FIRMSIZE & -63.08024 & 11.72769 & -5.378746 & 0.000000 \\
Ar(1) & 0.565717 & 0.027590 & 20.50437 & 0.000000 \\
\hline R-squared & 0.367750 & Mean dependent var & & 248.6148 \\
Adjusted R-squared & 0.366334 & s.d. dependent var & & 209.2488 \\
s.e. of regression & 166.5687 & Akaike info criterion & & 13.07203 \\
Sum squared resid & 24776394 & Schwarz criterion & & 13.08810 \\
Log likelihood & -5853.272 & Hannan-quinn criter. & & 13.07817 \\
F-statistic & 259.7075 & Durbin-watson stat & & 2.082535 \\
Prob(F-statistic) & 0.000000 & & \\
\hline Source Research Data (Computed from various years) & &
\end{tabular}

Source: Research Data (Computed from various years) 
Table 5. Hypothesis 2 Test Results

\begin{tabular}{crccr}
\hline Variable & Coefficient & Std. error & t-Statistic & Prob. \\
\hline C & 254.2945 & 14.92700 & 17.03587 & 0.0000 \\
BDIND & -11.85473 & 12.50210 & -0.948219 & 0.3433 \\
AR(1) & 0.587780 & 0.027133 & 21.66291 & 0.0000 \\
\hline R-squared & 0.348253 & Mean dependent var & & 248.8208 \\
Adjusted R-squared & 0.346791 & S.D. dependent var & & 209.4364 \\
S.E. of regression & 169.2694 & Akaike info criterion & & 13.10421 \\
Sum squared resid & 25529039 & Schwarz criterion & & 13.12030 \\
Log likelihood & -5854.582 & Hannan-Quinn criter. & & 13.11036 \\
F-statistic & 238.0480 & Durbin-Watson stat & & 2.101777 \\
Prob(F-statistic) & 0.000000 & & \\
\hline urce: Research Data (Computed from various years) & & &
\end{tabular}

Source: Research Data (Computed from various years)

From the above statistical presentations, Table 1 above shows that all the variables in the multiple regression model are relevant to the study, as the VIF of each is below the benchmark of 10; indicating the absence of multicollinearity in model. Table 2 with F-statistic and Obs*Rsquare values of 1.44 and 7.19 as well as p-values of 0.20 and 0.20 indicate the absence of heteroskedasticity in the model, since the F-statistic and Obs*Rsquare are greater than the critical values at $5 \%$ level of significance. In Table 3, the F-statistic and Obs *Rsquare values of 2.58 and 5.18 as well as p-values of 0.07 and 0.07 indicate the absence of autocorrelation in model, since the F-statistic and Obs*Rsquare are greater than the critical values at $5 \%$ level of significance.

The panel least square regression results for firm size indicates a calculated t-value of -5.37 with $p$-value of 0.00 , which is greater than the critical t-value of 2.0 at $5 \%$ level of significance; establishing that there is significant relationship between firm size and timeliness of financial reporting in the firms quoted on the NSE. The panel least square regression results for board independence, indicates a calculated t-value of -0.94 with p-value of 0.34 , which is less than the critical t-value of 2.0 at $5 \%$ level of significance; establishing that there is no significant relationship between board independence and timeliness of financial reporting of firms quoted on the NSE.

\section{Discussion}

This study has revealed that there is a significant relationship between firm size and timeliness of financial reporting, such that the larger the firm the higher the tendency to publish the financial reports in time. This supports the position of Atiase, Bamber \&Tse (1989), (Owusu-Ansah (2000) and Ahmed (2003), among others. Most firms quoted on the NSE are well to do in terms of resources, accounting staff and modern accounting information systems, which result in more timely annual reports. They also have strong internal control systems which make auditors to spend less time in conducting their compliance and substantive tests. Thus, audit delays are largely minimised, making the firms to report promptly to the public. On the other hand, the study has also revealed that there is no significant relationship between board independence and timeliness of financial reporting. This outcome is in line with the findings of $\mathrm{Wu}, \mathrm{Wu}, \&$ Liu (2008) and Kelton \& Young (2008), among others.

\section{Conclusion}

The results of this study have established a significant relationship between firm size and timeliness of financial in companies quoted on the NSE. The case of the board independence as a research variable was quite different as it recorded no significant relationship in the analysis. This implies that firms with more independent boards (represented by presence of many non-executive directors with the right skill sets, who have no administrative interest that could interfere with the exercise of independent judgment, may not likely act better in the best interest of the shareholders. Given the truly objective professional setting required of the quoted firms, the non-executive (more independent) directors are expected to complement the administrative framework by:

i. $\quad$ Being of a better disposition to show higher degree of impartiality; 
ii. Being more willing to ensure adequate protection of the interest of all shareholder;

iii. Being in a better position to monitor management activities than inside directors;

iv. Being more willing to manage the tendency of managerial opportunism, thereby decreasing the chances of withholding information which is crucial to the interest of stakeholders.

In the light of the findings from the analysis, the conclusions of this study are to the effect that firm size is significantly associated with timeliness of financial reporting; while board independence is no so associated. Even in the latter outcome, where there is no significant relationship, there is obvious need for the regulatory bodies, including the stock exchange as well as the Securities and Exchange Commission (SEC), to remain resolute in enforcing timely financial reporting standards and operating directives. The affected firms should also be more committed to the prompt release of their annual reports, as corporate defaulters are likely to face stiffer sanctions in the future, which would better serve as deterrent to others.

\section{References}

Abdulla, J. Y. A. (1996). The timeliness of Annual Reports. Advances in International Accounting, 9(2), 73-88.

Ahmed, K. (2003). A comparative study of timeliness of corporate financial reporting in South Asia. Advances in International Accounting, 16, 17-42. https://doi.org/10.1016/S0897-3660(03)16002-3

Amah, J. O. T. (2015). Concept of duty and care and professional negligence: Focus on lawyers, accountants and auditors. The Certified National Accountant, 23(5), 18-20.

Aondona, A. P. (2016). Dividend pay-out policy determinants and their influence on manufacturing companies in Nigeria. The Certified National Accountant, 42(2), 9-21.

Atiase, R. K., Bamber, L. S., \& Tse, S. (1989). Timeliness of financial reporting: The firm size effect, and stock price reactions to annual earnings announcements. Contemporary Accounting Research, 5(2), 526-552. https://doi.org/10.1111/j.1911-3846.1989.tb00722.x

Basu, S. (1997). The conservatism principle and the asymmetric timeliness of earnings. Journal of Accounting \& Economics, 24, 3-37. https://doi.org/10.1016/S0165-4101(97)00014-1

Beasley, M. S. (1996). An empirical analysis of the relationship between the board of directors' composition and financial statement fraud. The Accounting Review, 71(4), 443-465.

Bromwich, M. (1992). Financial Information and Capital Markets. London, England: Pitman.

Givoly, R., \& Palmon, S. (1982). Timeliness of annual earnings announcements: Some empirical evidence. The Accounting Review, 57, 486 - 508.

Haniffa, R. M., \& Cooke, T. E. (2002). Culture, corporate governance and disclosure in Malaysian corporations. Abacus, 38(3), 317-348. https://doi.org/10.1111/1467-6281.00112

Ilaboya O. J. (2005). Advanced Financial Accounting. Ibadan: Dalag.

Kelton, A. S., \& Yang, Y. (2008). The impact of corporate governance on internet financial reporting. Journal of Accounting and Public Policy, 27(1), 62-87. https://doi.org/10.1016/j.jaccpubpol.2007.11.001

Leventis, S., \& Weetman, P. (2004). Timeliness of financial reporting: Applicability of disclosure theories in an emerging capital market. Accounting and Business Research, 34(1), 43-56. https://doi.org/10.1080/00014788.2004.9729950

lyoha, F. O. (2012). Company attributes and the timeliness of financial reporting in Nigeria. Business Intelligence Journal, 5(1), 41-49.

Nwanyanwu, L. A. (2006). Funds flow and cash flow statements for corporate governance in the Nigerian public sector; in Corporate Governance: Readings and Rhythms, Port Harcourt: Sonite.

Owusu-Ansah, S. (2000). Timeliness of corporate financial reporting in emerging capital markets: Empirical evidence from the Zimbabwe stock exchange. Accounting and Business Research, 30(3), 241-254. https://doi.org/10.1080/00014788.2000.9728939

Spiejel, M. R., \& Stephens, L. J. (2011). Statistics: Schaum's Outlines. New York: McGraw Hill. 
Suphap, W. (2004). Getting it right versus getting it quick: The quality-timeliness tradeoff in corporate disclosure. Columbia Business Law Review, 23, 66 1-689.

Watts, R. L., \& Zimmerman, J. L. (1986). Positive Accounting Theory. Englewood Cliffs, New Jersey, USA: Prentice-Hall.

Whittred, G. (1980). Audit qualification and the timeliness of corporate annual reports. The Accounting Review, 55, 563-577.

Wu, C.H., Wu, C.S., \& Liu, V.W. (2008). The release timing of annual reports and board characteristics. The International Journal of Business and Finance Research, 2, 103-118. 